\title{
Peripheral thermal responses in normal and cold- sensitive individuals to sublingual Glyceryl Trinitrate (GTN)
}

\author{
Katrina Hope ${ }^{1 *}$, Clare M Eglin², Frank Golden², Michael J Tipton² \\ From 15th International Conference on Environmental Ergonomics (ICEE XV) \\ Portsmouth, UK. 28 June - 3 July 2015
}

\section{Introduction}

Non-freezing cold injury (NFCI) is caused by prolonged exposure of the extremities to cold. The long-term sequelae of NFCI, include cold-sensitivity and pain[1]. The cold sensitivity is characterised by a reduction in basal skin blood flow and augmented vasoconstriction during cold exposure. We tested the hypothesis that sublingual GTN would increase blood flow in the peripheral microcirculation during and after a mild cold challenge in individuals who had not been diagnosed with NFCI, but were cold-sensitive.

\section{Methods}

In air at $30^{\circ} \mathrm{C}$, seven control and six cold-sensitive participants undertook $12 \mathrm{~min}$ of gentle exercise prior to immersing their right foot (protected by a thin plastic bag) into $15{ }^{\circ} \mathrm{C}$ water for $2 \mathrm{~min}$, followed by $10 \mathrm{~min}$ of spontaneous rewarming. Two minutes prior to immersion, participants were given either $400 \mu \mathrm{g}$ GTN or placebo sublingually in a single-blinded, counter-balanced order. Toe pad skin temperature $\left(\mathrm{T}_{\mathrm{sk}}\right)$ and blood flow $(\mathrm{SkBF})$ were measured using infrared thermography and laser Doppler flowmetry respectively.

\section{Results}

In the placebo condition, $T_{\text {sk }}$ was significantly lower in Cold-sensitive participants compared to controls throughout the test $(\mathrm{P}<0.001)$ as was SkBF $(\mathrm{P}<0.05)$.

GTN increased the rate of rewarming $\left({ }^{\circ} \mathrm{C} \cdot \mathrm{min}^{-1}\right)$ and absolute $\mathrm{T}_{\text {sk }}$ of the coldest toe after the cold challenge in

\footnotetext{
* Correspondence: katrina.hope@bristol.ac.uk

'School of Physiology \& Pharmacology, Clinical Research and Imaging Centre (CRICBristol), University of Bristol, 60 St Michael's Hill, Bristol, BS2 8DX, UK

Full list of author information is available at the end of the article
}

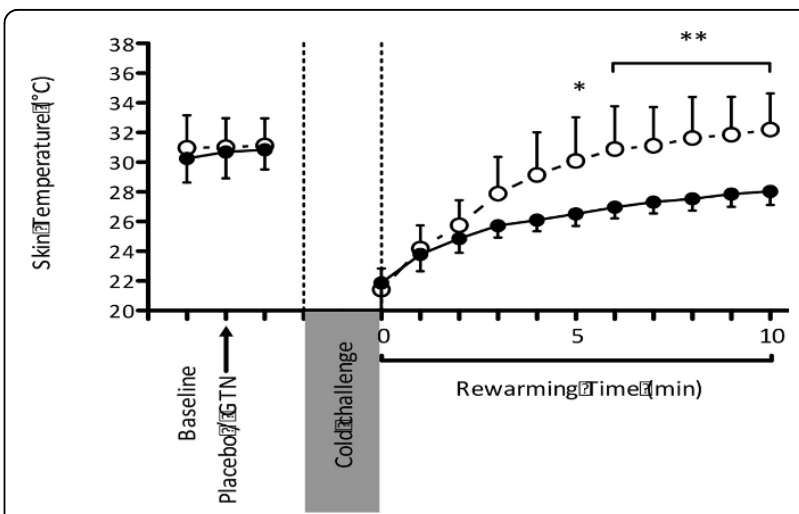

Figure 1 Mean (SD) $T_{s k}$ of coldest toe before and after foot immersion in $15^{\circ} \mathrm{C}$ water in Cold-sensitive group following placebo (I) or GTN (i) * $P<0.05,{ }^{* *} P<0.001$

Cold-sensitive (placebo: $0.62(0.14){ }^{\circ} \mathrm{C} \cdot \mathrm{min}^{-1}, 28.03(0.92){ }^{\circ} \mathrm{C}$; GTN: $\left.1.08(0.29){ }^{\circ} \mathrm{C} \cdot \mathrm{min}^{-1}, 32.20(2.43){ }^{\circ} \mathrm{C} ; \mathrm{p}<0.001\right)$ but not control individuals (Figure 1). GTN also increased the blood flow in the great toe during rewarming in some cold-sensitive individuals.

\section{Discussion}

We accept our hypothesis that impairment in the vasodilatory response seen in individuals with cold-sensitivity can be overcome by the use of GTN, an endothelialindependent nitric oxide donor, and thereby improve the rewarming of cooled peripheral tissues.

\section{Conclusion}

Individuals with cold-sensitivity show increased vasoconstrictory tone, both at rest and during warming after a cold stimulus, compared to controls. The use of GTN 
to overcome this implies an abnormal endothelium and nitric oxide pathway in this condition.

\section{Authors' details}

${ }^{1}$ School of Physiology \& Pharmacology, Clinical Research and Imaging

Centre (CRICBristol), University of Bristol, 60 St Michael's Hill, Bristol, BS2 8DX,

UK. ${ }^{2}$ Extreme Environments Laboratory, Department of Sport and Exercise

Science, University of Portsmouth, Portsmouth, UK.

Published: 14 September 2015

\section{Reference}

1. Ungley, Blackwood : Lancet 1942, 2:447-451.

doi:10.1186/2046-7648-4-S1-A34

Cite this article as: Hope et al: Peripheral thermal responses in normal

and cold-sensitive individuals to sublingual Glyceryl Trinitrate (GTN).

Extreme Physiology \& Medicine 2015 4(Suppl 1):A34.

Submit your next manuscript to BioMed Central and take full advantage of:

- Convenient online submission

- Thorough peer review

- No space constraints or color figure charges

- Immediate publication on acceptance

- Inclusion in PubMed, CAS, Scopus and Google Scholar

- Research which is freely available for redistribution

Submit your manuscript at www.biomedcentral.com/submit 